\title{
Blumeria graminis Interactions with Barley Conditioned by Different Single $R$ Genes Demonstrate a Temporal and Spatial Relationship Between Stomatal Dysfunction and Cell Death
}

\author{
Elena Prats, Alan P. Gay, Peter C. Roberts, Barry J. Thomas, Ruth Sanderson, Neil Paveley, \\ Michael F. Lyngkjær, Tim L. W. Carver, and Luis A. J. Mur
}

First author: Instituto de Agricultura Sostenible, CSIC, Alameda del Obispo, Menéndez Pidal s/n, 14080 Córdoba, Spain; second, third, fourth, fifth, eighth, and ninth authors: Institute of Biological, Environmental and Rural Sciences, Aberystwyth University, Aberystwyth, Ceredigion SY23 3EB, UK; sixth author: ADAS High Mowthorpe, Duggleby, Malton, North Yorkshire, YO17 8BP, UK; and seventh author: Department of plant Biology and Biotechnology, Faculty of Life Sciences, University of Copenhagen, Denmark.

Accepted for publication 28 July 2009.

\begin{abstract}
Prats, E., Gay, A. P., Roberts, P. C., Thomas, B. J., Sanderson, R., Paveley, N., Lyngkjær, M. F., Carver, T. L. W., and Mur, L. A. J. 2010. Blumeria graminis interactions with barley conditioned by different single $R$ genes demonstrate a temporal and spatial relationship between stomatal dysfunction and cell death. Phytopathology 100:21-32.

Hypersensitive response (HR) against Blumeria graminis f. sp. hordei infection in barley (Hordeum vulgare) was associated with stomata "lockup" leading to increased leaf water conductance $\left(g_{1}\right)$. Unique spatiotemporal patterns of HR formation occurred in barley with Mla1, Mla3, or MlLa R genes challenged with B. graminis f. sp. hordei. With Mlal, a rapid HR, limited to epidermal cells, arrested fungal growth before colonies initiated secondary attacks. With Mla3, mesophyll HR preceded

that in epidermal cells whose initial survival supported secondary infections. With MlLa, mesophyll survived and not all attacked epidermal cells died immediately, allowing colony growth and secondary infection until arrested. Isolines with Mlal, Mla3, or MlLa genes inoculated with $B$. graminis f. sp. hordei ranging from 1 to 100 conidia $\mathrm{mm}^{2}$ showed abnormally high $g_{1}$ during dark periods whose timing and extent correlated with those of each HR. Each isoline showed increased dark $g_{1}$ with the nonpathogen $B$. graminis $\mathrm{f}$. sp. avenae which caused a single epidermal cell HR. Guard cell autofluorescence was seen only after drying of epidermal strips and closure of stomata suggesting that locked open stomata were viable. The data link stomatal lock-up to HR associated cell death and has implications for strategies for selecting disease resistant genotypes.
\end{abstract}

Plants regulate gas exchange and transpiration largely by manipulating guard cell turgor, and hence stomatal aperture, in response to environmental factors including light, $\mathrm{CO}_{2}$, and water status (reviewed by Roelfsema and Hedrich [25]). Early observations (reviewed by Ayres [2]) indicating that pathogen attack may affect stomatal behavior have recently attracted further attention, and it is apparent that attack may lead to stomatal opening or closure according to the particular plant-pathogen system. Some pathogens have been shown to interfere with abscisic acid (ABA)modulated cell signaling which is known to mediate stomatal closure and inhibit stomatal opening $(9,16,26,31)$. Thus, ABA-induced stomatal closure can be inhibited by oxalate generated during Sclerotinia infection, thereby facilitating secondary spread of the fungus on certain dicotyledonous plants $(8,17)$. Also in Pseudomonas syringae interactions with Arabidopsis, the PAMP (pathogen associated molecular pattern) molecule flagellin (flg22) induces stomatal closure which is antagonized by the phytotoxin coronatine facilitating entry of the bacteria (20). Stomatal closure and opening function via two discrete mechanisms and it has recently been established that flg22 acts by initiating closure and inhibiting opening. In the latter case, flg22 acts, similar to ABA, via $\mathrm{G}$-protein mediated inhibition of inward rectifying $\mathrm{K}+$ channels to suppress guard cell swelling (32). Via possibly analo-

Corresponding author: E. Prats; E-mail address: elena.prats@ias.csic.es

*The $\boldsymbol{e}$-Xtra logo stands for "electronic extra" and indicates that Figure 9 appears in color online.

doi:10.1094/PHYTO-100-1-0021

(c) 2010 The American Phytopathological Society gous mechanisms, the stomata of susceptible barley infected by powdery mildew caused by the obligate biotrophic fungus Blumeria graminis DC Speer f. sp. hordei Marchal, lose the ability to open in response to light, greatly reducing leaf water conductance $\left(g_{1}\right)(3,23)$. In contrast to such situations, Prats et al. (23) showed that the rapid hypersensitive response (HR) of epidermal cells, due to race-specific resistance conditioned by the Mlal allele, leads to a loss of the ability of stomata to close. These "locked"open stomata were unable to shut in response to darkness, extreme drought, or ABA application. Thus, although this HR prevented disease development, attacked plants were severely physiologically compromised. These findings have potentially serious implications for the use of this form of race-specific powdery mildew resistance in field crops where plant water-use efficiency is a key consideration, e.g., in dry, summer conditions that also favor the disease and the dispersal of fungal wind-blown conidia.

The apparent potential for $B$. graminis $\mathrm{f}$. sp. hordei-induced HR to cause stomatal dysfunction in barley raises the question of the general role of cell death in the initiation of stomatal lock-up. Race-specific resistance to powdery mildew is conditioned by a large number of different major $(R)$ genes with some, for example at the Mla locus, existing in a large allelic series ( $\approx 30 \mathrm{Mla}$ alleles) (12). The numbers of plant cells that die, the rapidity of their death, and the localization of cell death to the epidermis or its additional exhibition in the mesophyll are related to the particular locus/allele responsible for the resistance $(4,11,15)$. In turn, the rapidity of cell death influences the amount of fungal growth before HR arrests further development. The terms fast, intermediate, and slow-acting have been used to describe the resistance conditioned by different alleles/genes (15) which can also be 
discriminated by their macroscopic response phenotype (14). Thus, barley isolines displaying different HR phenotypes can be used to test the relationship between the temporal and spatial expression of cell death and stomatal function.

We here describe microscopic analysis of infection progress in various barley isolines in which differing spatio-temporal patterns of HR in response to $B$. graminis $\mathrm{f}$. $\mathrm{sp}$. hordei are conferred by different single $R$ genes (Mlal, Mla3, or MlLa). Different patterns of cell death were associated with perturbations in circadian patterns of leaf water conductance $\left(g_{1}\right)$. The relevance of these observations to field conditions was demonstrated by showing analogous effects at a range of lower inoculum densities and also with a powdery mildew variant that is not pathogenic to barley, the oat mildew fungus $B$. graminis f. sp. avenae, on stomatal function. Finally, we here present evidence supporting the contention that locked stomata remain viable.

\section{MATERIALS AND METHODS}

Pathogen, plants, growth conditions, inoculation, and incubation. Isolate $\mathrm{CC} 1$ of $B$. graminis $\mathrm{f}$. sp. hordei and an isolate of $B$. graminis $\mathrm{f}$. $\mathrm{sp}$. avenae race 5 were maintained on barley $\mathrm{cv}$. Pallas and oat cv. Selma, respectively. Plants were shaken to remove ageing conidia 1 day before inoculum was required. The barley lines used were cv. Pallas and its near-isogenic derivatives (14) with differing $R$ genes here indicated in parenthesis P01 (Mla1), P02 (Mla3), and P23 (MlLa). Plants were grown individually in plastic tubes $(30 \times 110 \mathrm{~mm})(23)$ in a growth room at $20^{\circ} \mathrm{C}, 70 \%$ relative humidity with $12 \mathrm{~h}$ dark $/ 12 \mathrm{~h}$ light at $450 \mu \mathrm{mol} \mathrm{m} \mathrm{m}^{-2} \mathrm{~s}^{-1}$ photon flux density supplied by white fluorescent tubes.

When first leaves were expanded (10 to 11 days after planting), plants for inoculation were taken to a laboratory and controls to an adjacent one so that all experienced the same environmental fluctuations. Unless stated otherwise, inoculation was immediately before onset of the $12 \mathrm{~h}$ dark period using a settling tower (23) to apply 100 conidia $\mathrm{mm}^{-2}$ to the first leaf adaxial surface. All plants were then returned to the growth room.

Leaf water conductance $\left(g_{1}\right)$ in watered and droughted plants attacked by $B$. graminis f. sp. hordei, fungal development, and plant cell responses. As previously described (23), $g_{1}$ was measured in the center of the adaxial leaf surface using an AP4 cycling porometer (Delta-T Devices Ltd., Cambridge, UK). Experiment 1 examined effects of $B$. graminis f. sp. hordei attack on $g_{1}$ in well-watered plants of P02 and included Pallas and P01 as known checks (23). For each isoline, 20 tubes containing uniform plants were arranged as five pairs in each of two adjacent trays containing compost that was watered freely each day; one of each pair was inoculated with $B$. graminis f. sp. hordei and the other served as a healthy control. $g_{1}$ was measured $1 \mathrm{~h}$ before the end of each dark period and in the middle of each light period up to $90 \mathrm{~h}$ after inoculation (hai). All plants were measured within $45 \mathrm{~min}$ in a consistent sequence. All measurements were taken in the growth room where the plants were growing.

For microscope assessment of fungal development and plant cell responses, nine additional plants of each line were inoculated and arranged in a completely randomized design and incubated in the same growth room. At 35, 59, and 90 hai, the central $30 \mathrm{~mm}$ leaf segment was excised from three plants per line and fixed, cleared and stained with $1 \%$ aniline blue (18), and examined by transmitted light, differential interference contrast (DIC) and incident fluorescence microscopy (blue exciter filter, max transmittance $480 \mathrm{~nm}$; dichroic mirror and barrier filter transmittance $>530 \mathrm{~nm}$ ). Outcomes of primary attacks and associated plant responses were determined on each leaf fixed 35 hai by examining 50 primary appressoria on different type A epidermal cells (adjacent to stomata; [13] attacked by a single appressorium). Notes were made of whether attempted penetration had succeeded (haustorium present) or failed and whether the epidermal cell and directly underlying mesophyll cells had died. On leaves fixed 59 and 90 hai, many established colonies had formed secondary hyphal appressoria and their hyphae were often entangled so that individual colonies could not be discriminated. Therefore, 50 randomly selected appressoria (including primary and secondary) on different type A cells were examined and the outcomes of attack and host response were recorded. For statistical analysis, 95\% confidence intervals were calculated with the GenStat 7.0 software (VSN International, UK) from 50 randomly selected attack sites on each of three replicate leaves from every barley line at all sample times.

Finally, to estimate the frequency with which stomata lay close to fungal attack sites, three leaves from randomly selected, inoculated plants that had been used for $g_{1}$ measurements were fixed after the final measurements (90 hai) and prepared for microscopy. On each, type A epidermal cells adjacent to 40 randomly selected stomatal complexes were examined and notes taken of whether they were in contact with appressoria, contained haustoria, and whether they or the underlying mesophyll were dead.

Experiment 2 was similar to experiment 1 but had drought imposed during the later stages and isolines Pallas, P02, and P23 were used. Initially, plants were well watered but after measuring $g_{1}$ at 66 hai all tubes were transferred to racks allowing the compost to dry progressively. Measurements of $g_{1}$ continued up to 90 hai and further measurements taken in the light were recorded at 114 and 138 hai before a final measurement in the dark at 155 hai. Again, separate plants were produced for microscopy and these continued to receive water until 83 hai when the final samples were fixed. Fungal development and host response observations were made as for experiment 1 but in this case, the association of stomatal complexes with fungal attack and response of type A cells was assessed using the leaves fixed 83 hai.

Low temperature scanning electron microscopy (LTSEM). Five-millimeter-square pieces excised from inoculated leaves of Pallas, P02, and P23 at 59 and 83 hai (i.e., in darkness) were prepared and observed by LTSEM as described previously (23).

Effects of $B$. graminis f. sp. hordei inoculum density on $g_{1}$ in P02 and P01. In an initial experiment, six tubes containing individual P02 plants were arranged in each of 10 trays, each tray representing one replicate. One plant in every tray served as an uninoculated control, while the others were inoculated with either $\approx 100,80,60,40$, or 20 conidia $\mathrm{mm}^{-2}$. As described above, $g_{1}$ was measured $1 \mathrm{~h}$ before the end of each dark period and in the middle of each light period up to 90 hai and then again at 155 hai (in darkness) and at 162 hai. This experiment was repeated but the second time using $\approx 100,20,10,5$, or 1 conidia $\mathrm{mm}^{-2}$. Finally, a third experiment used P01 plants inoculated with $\approx 100,50,20$, 10 , or 1 conidia $\mathrm{mm}^{-2}$. Here, the lighting system for four of the replicates malfunctioned 2 days before inoculation so these were discarded and only the remaining six replicates were used.

$g_{1}$ in plants attacked by the nonhost $B$. graminis f. sp. avenae, fungal development, and plant cell responses. The design for assessing $g_{1}$ was similar to experiment 1 , but plants used were Pallas, P02, and P03, and plants were inoculated with $B$. graminis f. sp. avenae. Segments from three extra plants of each line were prepared for microscopy at 35 hai and then at 90 hai. Further segments were taken from three randomly selected, inoculated leaves used for $g_{1}$ measurement. On each segment, 40 randomly selected stomatal complexes and associated type A epidermal cells were examined to determine whether they were in contact with appressoria, whether they contained haustoria, and whether they or the underlying mesophyll were dead. Assessments of fungal development were derived from these observations.

Effects of ABA on $g_{1}$ in P02 and P23. Ten pairs of P02 and P23 plants were grown in a similar design to experiment 1 but here inoculation was performed $5 \mathrm{~h}$ before the beginning of the 
dark period. $g_{1}$ of inoculated and healthy leaves was measured 64 hai ( $1 \mathrm{~h}$ before the end of the third dark period) and again at 69 hai (4 h into the third light period). Starting at 69.5 hai, leaves were sequentially immersed for $5 \mathrm{~s}$ in $100 \mu \mathrm{M}$ ABA. This was completed within $15 \mathrm{~min}$, and $g_{1}$ was remeasured $30 \mathrm{~min}$ after ABA application when leaves appeared dry.

Assessment of chlorophyll fluorescence in stomata. The abaxial epidermis of barley can be removed easily to provide a single cell layer with few remnants of underlying mesophyll. The abaxial surface of P01, P02, and P23 leaves were inoculated with $\approx 50$ B. graminis $\mathrm{f}$. $\mathrm{sp}$. hordei conidia $\mathrm{mm}^{-2}$. For $\mathrm{P} 01$, inoculation was immediately before onset of the first light period and epidermal strips were made in the middle of the third dark period, (52 hai). For P02 and P23, inoculation was $7 \mathrm{~h}$ before onset of the first light period and strips were made $1 \mathrm{~h}$ before the end of the third dark period, (66 hai). Strips were laid adaxial surface up on a $1 \mathrm{~mm}$ layer of $1 \%$ agarose on a microscope slide and immediately observed using transmitted white light and incident blue light. Under blue light, dead type A cells showed yellow-green whole-cell autofluorescence and adjacent stomata were examined to determine whether they were open and whether red fluorescent chloroplasts could be seen within the guard cells. At least two epidermal strips from each barley line were examined, and digital images of a total of at least 25 relevant stomata were captured. The epidermal strips were then allowed to dry naturally and reexamined $\approx 17 \mathrm{~h}$ later.

\section{RESULTS}

Fungal development and plant cell responses to $B$. graminis f. sp. hordei attack in Pallas, P01, P02, and P23. In order to relate stomatal behavior to differential responses of the barley isolines with different $R$ genes to $B$. graminis $\mathrm{f}$. $\mathrm{sp}$. hordei, the interaction was characterized at the cytological level. Primary appressoria of B. graminis f. sp. hordei formed haustoria by 35 hai, and then elongating hyphae (Figs. 1 and 2) on Pallas, P02 (Mla3), and P23 (MlLa) became increasingly entangled and individual colonies became difficult to distinguish. No hyphal (secondary) appressoria had formed by 35 hai, so data (Figs. 3 and 4) from this time relate solely to attacks by primary appressoria. After this, however, colonies progressively produced hyphal (secondary) appressoria (Fig. 2A to C) so that data from 59 and 90 hai (Figs. 3 and 4) increasingly reflect the outcomes of secondary attacks. As previously reported (23), plant cell death due to $B$. graminis $\mathrm{f}$. sp. hordei attack was recognized by whole-cell autofluorescence and/or stain uptake or cytoplasmic disorganization (Fig. 1B to F).

In Pallas, $\approx 42 \%$ of primary appressoria had penetrated to form haustoria by 35 hai (Figs. 3A and 4A) and all penetrated epidermal and underlying mesophyll cells survived (Fig. 3B and C; Fig. 4B and C). Where primary penetration failed (Figs. 3E and 4E), most cells also survived (Fig. 3F and G; Fig. 4F and G) indicating that papillae had prevented penetration (7). However, as typical (23), even on susceptible Pallas a few failed attacks killed epidermal cells (Figs. 3I and 4I) although mesophyll cell death was rare (Fig. $3 \mathrm{H}$ and J; Fig. $4 \mathrm{H}$ and J). Virtually all secondary attacks by hyphal appressoria penetrated successfully so that the overall percentage of successful penetrations increased steadily with time (Figs. 3A and 4A) and the percentage of failures decreased concomitantly (Figs. 3E and 4E).

In P01, significantly fewer primary appressoria formed haustoria $(\approx 21 \%$, Fig. 3 A) compared with Pallas at 35 hai, and no further haustoria were produced because penetrated cells died rapidly ( $\approx 84$ and $100 \%$ dead by 35 and 59 hai, respectively; Figs. $1 \mathrm{~B}$ and $3 \mathrm{~B})$. A high percentage of penetrated dead epidermal cells also overlaid dead mesophyll cells (Fig. 3C) so that by 35 hai almost all penetrated sites were associated with cell death (Fig. $3 \mathrm{D})$. In addition, by 35 hai many $(\approx 53 \%$; Fig. $3 \mathrm{~F})$ failed appres- soria were associated with epidermal cell death, but underlying mesophyll cells rarely died (Fig. 3G). Thus, confirming previous work, the resistance of P01 was largely due to rapid epidermal cell death (Fig. 3I) associated with some mesophyll cell death (Fig. 3J) if haustoria formed.

Pallas and P02 were similarly susceptible to primary penetration (Figs. 3A and 4A). Failed attacks on P02 (Figs. 3E and 4E) caused epidermal cell death relatively infrequently (Figs. $3 \mathrm{~F}$ and $4 \mathrm{~F}$ ), and unlike P01 most penetrated cells also remained alive at 59 hai (Figs. 3B and 4B). Nevertheless, the percentage of penetrated cells that were dead in $\mathrm{P} 02$ had increased dramatically by the final sample time ( $\approx 80 \%$; Figs. $3 \mathrm{~B}$ and $4 \mathrm{~B})$. This epidermal death was preceded by death of underlying mesophyll since even at 35 hai dead mesophyll cells underlay a high percentage of penetrated epidermal cell that were alive at this time (Figs. 3C and 4C). Hence, the resistance of P02 was due to delayed response that eventually led to high frequencies of epidermal and/or mesophyll cell death (Figs. 3I to K and 4I to K).

Yet another pattern was evident in P23. Frequencies of failed primary penetration and associated epidermal cell death at 35 hai were slightly higher than in Pallas and P02 (Fig. 4E and F), but neither effect was significant. As in Pallas and P02, most penetrated epidermal cells survived at 59 hai (Fig. 4B) but unlike P01 and P02 underlying mesophyll cells also survived (Fig. 4C). Colonies on P23 therefore initiated secondary attacks but, in contrast to those on Pallas and P02, these frequently killed epidermal cells before haustoria formed (Figs. 1E and 4F) although underlying mesophyll cells mostly survived (Figs. 1E and 4G). However, where haustoria formed, frequencies of epidermal cell and/or underlying mesophyll cell death at 59 hai remained as low as in Pallas (Figs. 4B to D). At 90 hai, the percentage of failed appressoria associated with cell death remained high (Fig. 4F), but in addition, a moderate percentage of penetrated epidermal cells containing haustoria formed earlier were now dead (Fig. 4B) although the underlying mesophyll survived (Fig. 4C). Thus, the resistance of P23 was in part due to the rapid death of cells attacked by appressoria, and this effect was most marked in the secondary phase, but many infected cells survived for some time to support continued colony growth although some of these also died eventually.

Differential effects of $B$. graminis f. sp. hordei attack on stomatal behavior in susceptible barley cv. Pallas and the resistant lines P01 (Mla1), P02 (Mla3), and P23 (MlLa). Measurements of leaf water conductance $\left(g_{1}\right)$ in well-watered plants. In experiments 1 and 2, $g_{1}$ of well-watered healthy and inoculated leaves of the barley lines was assessed successively over several days in mid-light period and $1 \mathrm{~h}$ before the end of the $12 \mathrm{~h}$ dark period (Fig. 5). As expected (23), $g_{1}$ in healthy leaves was high in light and low in darkness, and in inoculated leaves of all lines $g_{1}$ was somewhat depressed at the end of the first dark period (11 hai) and substantially reduced in the first light period (18 hai). Hence, early $R$ gene-mediated responses to $B$. graminis f. sp. hordei had no differential effect on stomatal function.

As colonies developed further on Pallas, leaves in darkness showed low $\mathrm{g}_{\mathrm{l}}$, similar to healthy leaves (Fig. 5). LTSEM confirmed that stomata in the vicinity of colonies were closed (Fig. $2 \mathrm{~A}$ and $\mathrm{D}$ ), and their $\mathrm{g}_{\mathrm{l}}$ in light remained far lower than healthy leaves indicating impairment of stomatal opening (Fig. 5). Inoculated P01 also showed reduced $g_{1}$ in light but from 35 hai $g_{1}$ remained high in darkness. From this time, values of $g_{1}$ taken during light and dark periods were very similar.

Crucially, Figure 5 shows distinct $\mathrm{g}_{1}$ responses in P02 and P23 at 35 hai when epidermal cell death in both genotypes was relatively infrequent compared with P01 (Fig. 4), inoculated P02 and P23 showed $\mathrm{g}_{1}$ only slightly increased (Fig. 5). Therefore, even though in P02 dead mesophyll often underlay penetrated, living epidermal cells and with P23 some epidermal cells were dead (Fig. 1), these deaths had little immediate effect on stomatal clo- 
sure at 35 hai. However, by 59 hai (dark period), $g_{1}$ of inoculated P02 and P23 was substantially greater than the noninoculated controls and LTSEM showed that stomata near dead epidermal cells were generally open (Fig. 2B and C). By this time, most epidermal cells remained alive in $\mathrm{P} 02$, and mesophyll death frequency had not increased since 35 hai (Fig. 1), possibly indicating a delayed response by stomata to this earlier death. In P23, where, by contrast, mesophyll cell death was very infrequent, effects on $g_{1}$ corresponded with the high frequency of epidermal cell death associated with failed secondary attack at 59 hai (Fig. 1).

In the next dark period (83 hai) $g_{1}$ was very high in wellwatered P02 but also in P02 and P23 plants growing in compost just starting to dry (Fig. 5). At this time, cell death in P02 was frequent not only in underlying mesophyll but also in penetrated epidermal cells while in P23 many penetrated epidermal cells were now also dead although mesophyll remained alive (Figs. 1, 3 , and 4). LTSEM confirmed that most stomata near to dead epidermal cells of P02 and P23 remained open at the end of this dark period (Fig. 2D, E, and F).

Attack by B. graminis $f$. $s p$. hordei compromises the ability of Pallas, P02, and P23 to respond to drought. When water was withheld from healthy Pallas, P02 and P23 plants from 67 hai, $g_{1}$ in subsequent light periods decreased progressively (Fig. 5, experiment 2), indicating that developing water stress increasingly repressed stomatal opening. By 138 hai all healthy lines showed very low $g_{1}$ but the $g_{1}$ of attacked P02 and P23 leaves was largely unaffected. In inoculated Pallas, $g_{1}$ in the later light periods remained lower than in healthy leaves up to 114 hai, and at about the same level as seen before withdrawal of water. However, at 138 hai, when healthy leaves showed greatly reduced $g_{1}$, inoculated leaves maintained a relatively high $g_{1}$ that increased further
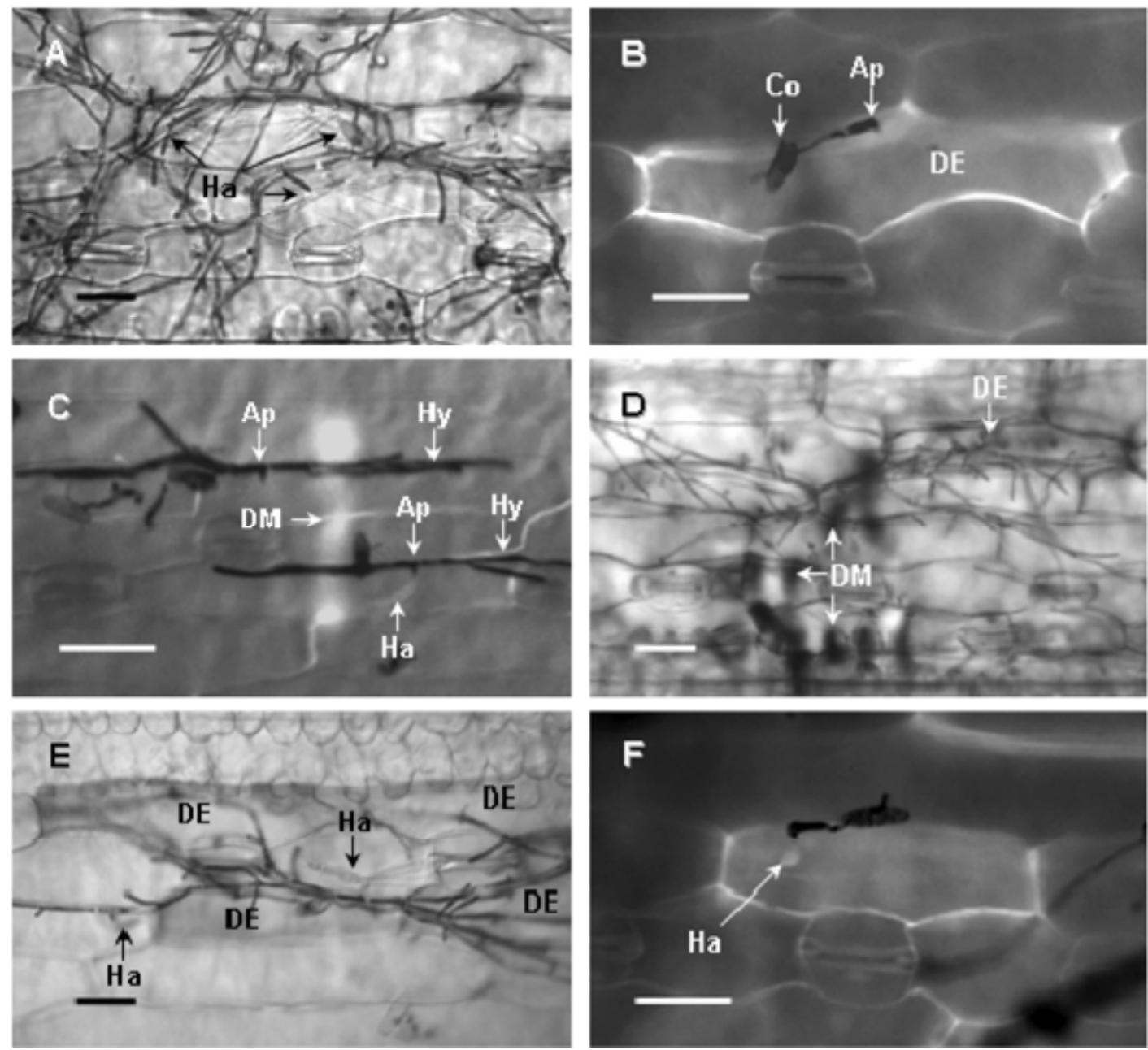

Fig. 1. Transmitted light and incident fluorescence micrographs of various stages of $\mathbf{A}$ to $\mathbf{E}$, Blumeria graminis f. $\mathrm{sp}$. hordei and $\mathbf{F}$, B. graminis f. sp. avenae development and plant cell response in the barley cv. Pallas and its isogenic derivatives P01, P02, and P23. Ap = appressorium; Co = conidium; DE $=$ dead epidermal cell; $\mathrm{DM}=$ dead mesophyll cell; $\mathrm{Ha}=$ haustorium; $\mathrm{Hy}=$ hyphae. Bar $=50 \mu \mathrm{m}$ in all cases. A, Pallas $59 \mathrm{~h}$ after inoculation (hai), transmitted light. Extensive hyphal development with many haustoria present (only some are indicated) in epidermal cells that were alive until fixation as indicated by their failure to take up trypan blue stain and the absence of whole-cell autofluorescence (not shown). B, The barley Mlal isogenic line P01 35 hai, blue incident light. The epidermal cell attacked by the primary appressorium was dead at fixation as indicated by whole-cell autofluorescence. Death occurred prior to formation of a visible haustorium and no hyphae developed. C, The barley Mla3 isogenic line P02 35 hai, blue incident light. Epidermal cells beneath the primary appressoria of two colonies contain a primary haustorium (visible beneath lower), and survived until fixation as indicated by absence of whole-cell autofluorescence and failure to stain. However, mesophyll cells beneath the infected epidermal cells show strong autofluorescence indicating that they were dead by the time of fixation. D, P02 59 hai, transmitted light. Many mesophyll cells underlying developing colonies are dead as indicated by their dark staining. However, only one epidermal cell is dead (upper right) while most were alive as indicated by their failure to stain and absence of whole-cell autofluorescence (not shown). E, The barley MlLa isogenic line P23 59 hai, transmitted light. Hyphae have developed and the primary haustorium visible in a surviving epidermal cell near the center of the picture and a secondary haustorium (left) is present in a different epidermal cell that survived attack. However, many surrounding cells attacked by hyphal appressoria show stain uptake (and were autofluorescent; not shown) indicating their death as a result of attack from appressoria formed by developing hyphae. Note: underlying mesophyll are alive as indicated by lack of staining. F, Pallas 35 hai, blue incident light. The epidermal cell attacked by the primary appressorium B. graminis $\mathrm{f}$. sp. avenae is dead as indicated by whole-cell autofluorescence. In this case, an immature haustorium formed before the cell died is associated with accumulated autofluorogenic material, but no hyphae developed. 
in the subsequent dark period (155 hai). In these later stages, Pallas leaves were totally covered by sporulating colonies and became increasingly senescent so that at 155 hai leaf tips were desiccated, and the experiment was terminated. The high $g_{1}$ values obtained in the latter stages may reflect disease-induced leaf-cell death.

Frequencies and outcomes of B. graminis $f$. sp. hordei attacks on type A epidermal cells. It was important to be able relate $g_{1}$ data (Fig. 5) to the proximity of stomatal complexes to pathogen attacks and their outcomes. Light microscopy of leaves from experiments 1 and 2 and fixed 83 and 90 hai, showed that in Pallas, P02, and P23 a very similar proportion ( $\approx 58$ to $61 \%$; Table 1) of stomatal complexes were adjacent to at least one type A cell with appressorial contact. In P01, where epidermal cell death mostly arrested colony development before hyphal appressoria were formed (Fig. 1B), significantly fewer stomata were adjacent to attacked type A cells $(\approx 43 \%)$. Further, due to rapid epidermal cell death in P01, no stomata lay adjacent to living epidermal cells containing haustoria, whereas in Pallas $\approx 20 \%$ of stomata did so (Table 1). Delayed epidermal cell death in P23 reduced this frequency substantially and significantly $(\approx 14 \%)$, but not to the extent seen in $\mathrm{P} 02$ where only $\approx 6$ to $8 \%$ of stomata were adjacent to living epidermal cells with haustoria. Conversely, very few stomata in Pallas were next to dead epidermal or mesophyll cells whereas many ( $\approx 48$ to $51 \%$ ) did so in P02 and P23. In P01, the frequency was a little lower $(\approx 37 \%)$ than in the other resistant lines because no secondary attacks had been initiated to cause cell death.

Effects of inoculum density on the time course of $g_{1}$ changes in P02 and P01. Here, and in previous investigations (23), inoculum densities of 100 conidia $\mathrm{mm}^{-2}$ were used. As the kinetics and spatial display of cell death (Figs. 3 and 4) affected patterns of $g_{1}$ change (Fig. 5), it seemed possible that inoculum density could influence the stomatal lock-up phenomenon.
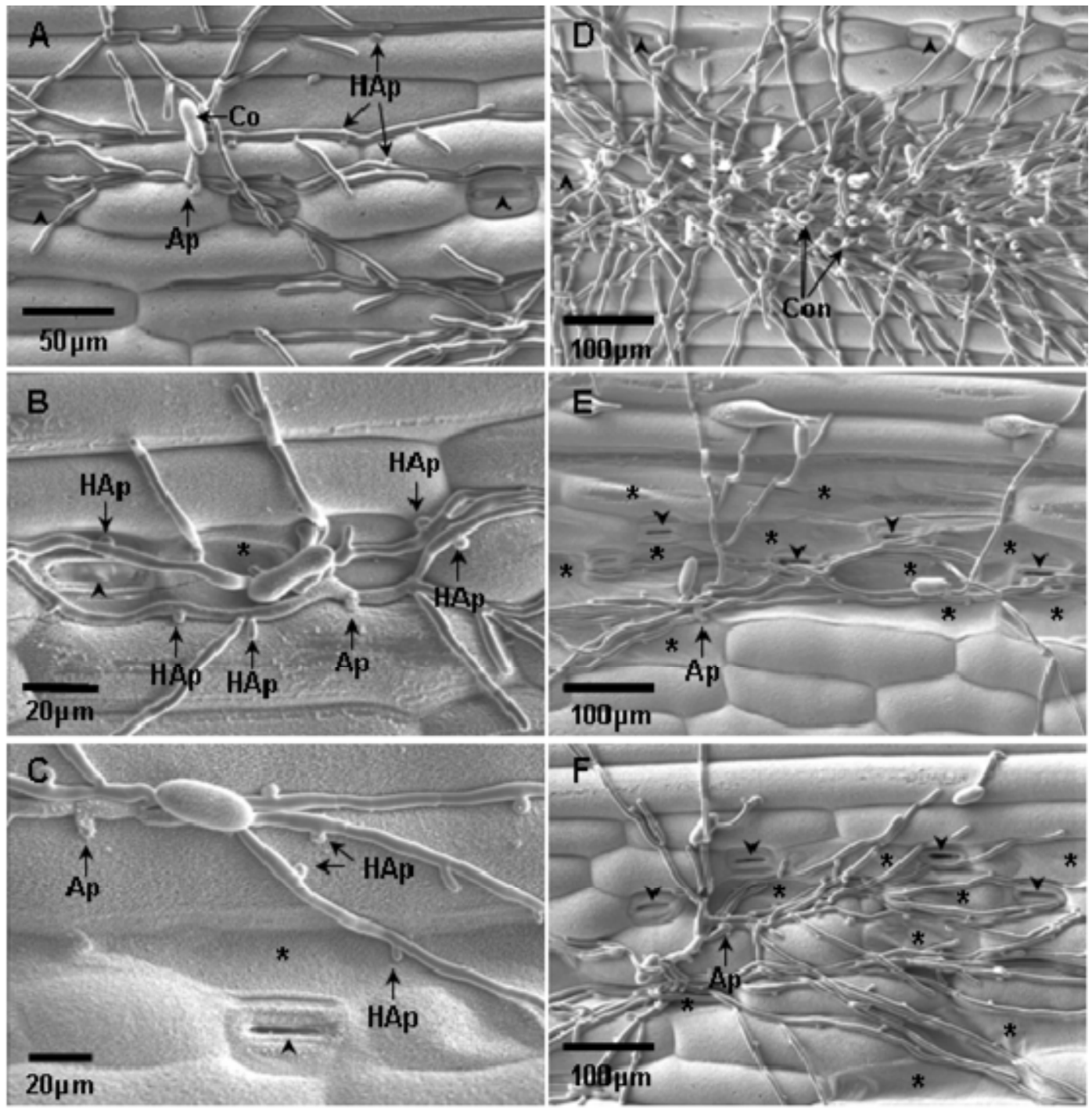

Fig. 2. Low temperature scanning electron micrographs of Blumeria graminis f. sp. hordei development on barley lines $\mathbf{A}$ and $\mathbf{D}, \mathrm{Pallas}$, $\mathbf{B}$ and $\mathbf{E}, \mathrm{P} 02$, and $\mathbf{C}$ and F, P23 cryofixed during darkness at $\mathbf{A}$ to $\mathbf{C}, 59$ and $\mathbf{D}$ to $\mathbf{F}, 83 \mathrm{~h}$ after inoculation (hai). Ap = primary appressorium; Co $=$ conidium; Con $=$ conidiophores; $\mathrm{HAp}=$ hyphal appressorium; arrowheads indicate stomata; asterisks indicate dead epidermal cells. A and D, On susceptible Pallas, well-established colonies with branching hyphae and several hyphal appressoria (some are indicated) are evident by A, 59 and $\mathbf{D}, 83$ hai and many conidiophores have been formed. All epidermal cells within the vicinity of colonies are turgid indicating that they were alive at the time of fixation, and all visible stomata are closed, as expected during darkness. B and E, On P02 with Mla3 resistance, by B, 59 hai this colony is similar to those on A, Pallas and cells underlying appressoria remain turgid, but here a single epidermal cell has died (and collapsed) despite having no direct contact with an appressorium, and the adjacent stoma (left) is open. E, By 83 hai hyphal development is less extensive than on B, Pallas and no conidiophores have formed. Many epidermal cells in the colony's vicinity, including that underlying the Ap, have died and nearby stomata are open. C and F, On P23 with MlLa resistance, by $\mathbf{C}, 59$ hai the colony is again well developed and many epidermal cells underlying appressoria (including the primary) remain turgid although that underlying the lowermost hyphal appressorium has died and the subadjacent stoma is open. F, By 83 hai, hyphal development is similar to that seen on E, P02 and no conidiophores have formed. Many epidermal cells in the colony's vicinity have died and nearby stomata are open but the cell underlying the appressorium, and containing the primary haustorium, remains turgid and alive. 
The time course of $g_{1}$ changes in P02 and P01 leaves inoculated with between 1 and 100 conidia $\mathrm{mm}^{-2}$ is shown in Figure 6 where data from successive samples taken in light and darkness are presented separately to clarify their respective effects on stomatal opening and closure in attacked leaves. In P02 leaves sampled in light, 10 to 100 conidia $\mathrm{mm}^{-2}$ had a similar suppressive effect on $g_{1}$ (Fig. 6A and B). The effect was significant at 18 hai but increased by 42 hai and remained substantial and similar until the final reading. The effects of 1 and 5 conidia $\mathrm{mm}^{-2}$ were not significant until 42 hai but thereafter only relatively small differences in light $g_{1}$ were evident between all densities. Dark measurements (Fig. 6A and B) showed that 100 conidia $\mathrm{mm}^{-2}$ caused the expected small but significant reduction in $g_{1}$ by 11 hai, and this effect was also significant with densities as low as 20 conidia $\mathrm{mm}^{-2}$. As expected from the rarity of cell death in P02 at 35 hai (Fig. 1), there was little effect of any inoculum density at this time, while by 59 hai, the 100 conidia $\mathrm{mm}^{-2}$ inoculation had substantially increased $g_{1}$ (Fig. 6A and B). All other densities except 1 conidium $\mathrm{mm}^{-2}$ also had significant but lesser effects at 59 hai, with the magnitude of effect ranking with density. However, the effect of lower densities increased over time so that even with 1 conidium $\mathrm{mm}^{-2}$ the effect was marked and significant by 155 hai. Thus, although rank order was maintained, the range of difference between $g_{1}$ values from high and low density inoculations decreased as time passed (Fig. 6B). Hence, even with low levels of inoculum, the delayed cell death associated with the Mla3 allele caused substantial suppression of stomatal opening in light and eventually impeded closure in darkness.
The behavior of P01 plants inoculated with different inoculum densities was different than that observed in P02. In the light, 100 and 50 conidia $\mathrm{mm}^{-2}$ suppressed $g_{1}$ from 18 hai onwards (Fig. 6C) but although effects of inoculation 20 and 10 conidia $\mathrm{mm}^{-2}$ were also evident at 18 hai, these were more prominent at later times. Although 1 conidium $\mathrm{mm}^{-2}$ had no detectable effect at 18 hai, thereafter a suppressive effect was evident. In darkness, 100 conidia $\mathrm{mm}^{-2}$ caused significantly lower $g_{1}$ than controls by 11 hai, and a similar and significant effect was associated with all other inoculum densities (Fig. 6C). At 35 hai, inoculation with 10 to 50 conidia $\mathrm{mm}^{-2}$ had little effect on $g_{1}$, but by 59 hai had significant effects which were proportional with conidial density; effects which were more marked by 83 hai, By 155 hai, the tips of leaves inoculated with 100,50 , or 20 conidia $\mathrm{mm}^{-2}$ were necrotic so that the observed decrease in $g_{1}$ (Fig. 6C) must be treated cautiously. Inoculation with 1 conidium $\mathrm{mm}^{-2}$ had no significant effect in $g_{1}$ values recorded in darkness at 11 hai or thereafter. Thus, with very low inoculum density the rapid response associated with the Mlal allele, resulting in relatively infrequent plant cell death, has only a modest overall effect on transpiration in the light, and little or no significant effect in the dark. However, higher inoculum densities rapidly depress stomatal opening in the light and in darkness stomatal lock-open becomes accentuated over time even though with 100 conidia $\mathrm{mm}^{-2}$ cell death frequency remains unchanged (Fig. 3).

Barley lines Pallas, P01, and $\mathrm{P02}$ respond similarly to attack by $B$. graminis f. sp. avenae, a nonhost forma specialis. Light microscopy (data not shown) of B. graminis f. sp. avenae
Successful penetration (with haustoria)
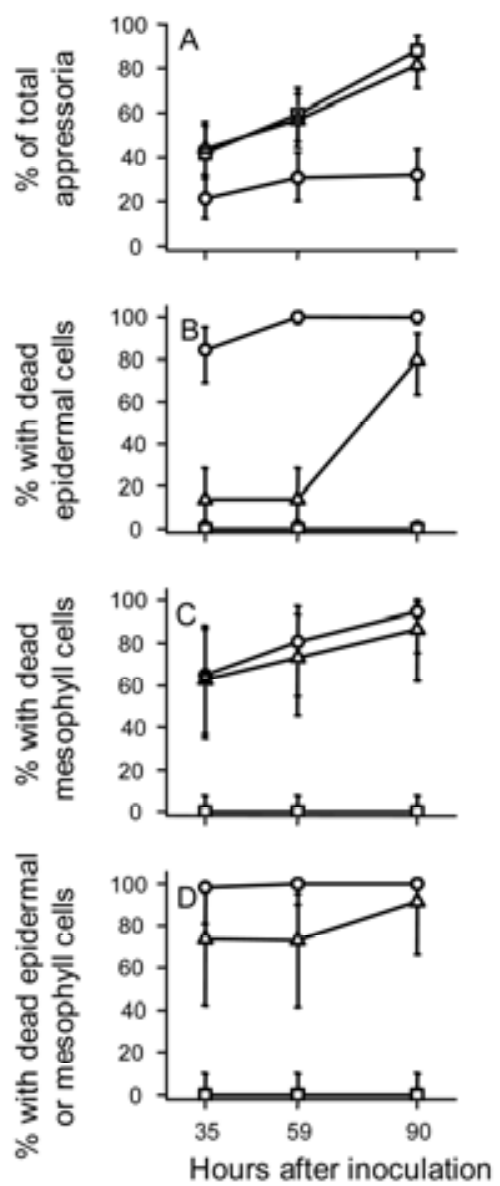

Failed penetration (no haustorium)
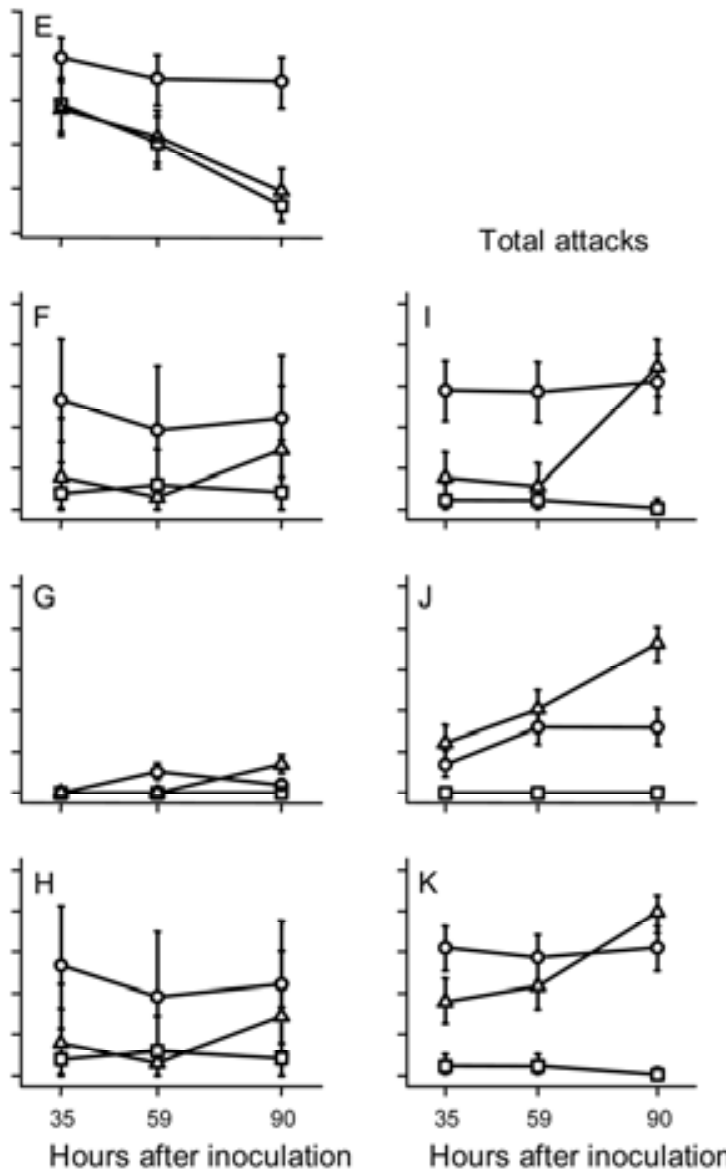

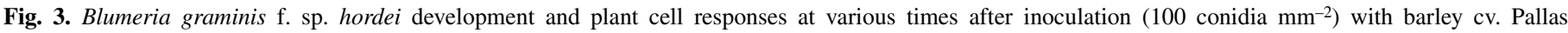

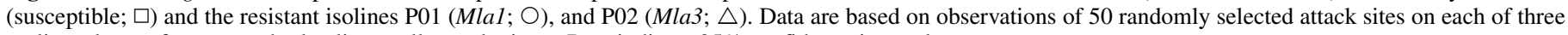
replicate leaves from every barley line at all sample times. Bars indicate $95 \%$ confidence intervals. 
development and plant cell response in Pallas, P01, and P02 indicated that development of this nonhost forma specialis was arrested by 35 hai. Only $2 \%$ or less of attacks formed a haustorium, and wherever they formed a haustorium the plant cell was dead by this time. Slightly less than $50 \%$ (no significant differences between lines) of appressoria that failed to form haustoria caused death of the single epidermal cell under attack (Fig. 1F) while the remainder were associated with papilla formation. No mesophyll cell death occurred. In leaves fixed at 90 hai, around $60 \%$ of stomatal complexes were adjacent to type A epidermal cells in contact with appressoria, and around $40 \%$ of complexes were adjacent to an epidermal cell killed by attack. There were no significant differences between barley lines for either characteristic.

Unlike with $B$. graminis f. sp. hordei, inoculation with $B$. graminis f. sp. avenae had no significant effect on $g_{1}$ at 11 hai in any barley line. However, by 18 hai and in subsequent light periods, inoculation led to reduced $g_{1}$ in all lines (Fig. 7) indicating that defense responses had permanently impaired stomatal opening in light. Impairment of closure in darkness also occurred as, from 35 hai, $g_{1}$ remained significantly greater for inoculated leaves and dark $g_{1}$ increased in all lines after 35 hai. Hence, as in barley expressing HR due to single gene, race-specific resistance, cell death resulting from the basic incompatibility between barley and B. graminis f. sp. avenae also led to stomatal lock-up.
Stomata of $B$. graminis f. sp. hordei-inoculated P02 and P23 leaves fail to respond to ABA. Exogenous application of ABA caused rapid stomatal closure in healthy P01 plants but had no effect on inoculated P01 after execution of HR (23). We therefore examined the generality of this phenomenon using P02 and P23 (Fig. 8). Healthy leaves of both lines showed low $g_{1}$ in the dark period preceding treatment (64 hai), much higher $g_{1}$ in the light immediately before treatment (69 hai), and very low $g_{1} 30 \mathrm{~min}$ after ABA application (70 hai). This contrasted dramatically with the situation in inoculated leaves where high $g_{1}$ was recorded before and after treatment in both lines.

Evidence that stomatal dysfunction is not due to guard cell death. All stomata were closed in epidermal strips collected from healthy P01 leaves during a dark period, but in strips from inoculated leaves open stomata adjacent to epidermal cells with appressorial contact could be located relatively easily even though some fungal structures were displaced during stripping (Fig. 9A). Under incident blue light, attacked epidermal cells showed green whole cell autofluorescence indicating that they were dead. No autofluorescence could be seen in the adjacent guard cells indicating that they were alive (Fig. 9B). In addition, living guard cells showed red chlorophyll fluorescence which was clearly associated with intact, and therefore presumably functional, chloroplasts. When strips were allowed to air dry, the guard cells developed whole cell autofluorescence
Successful penetration (with haustoria)
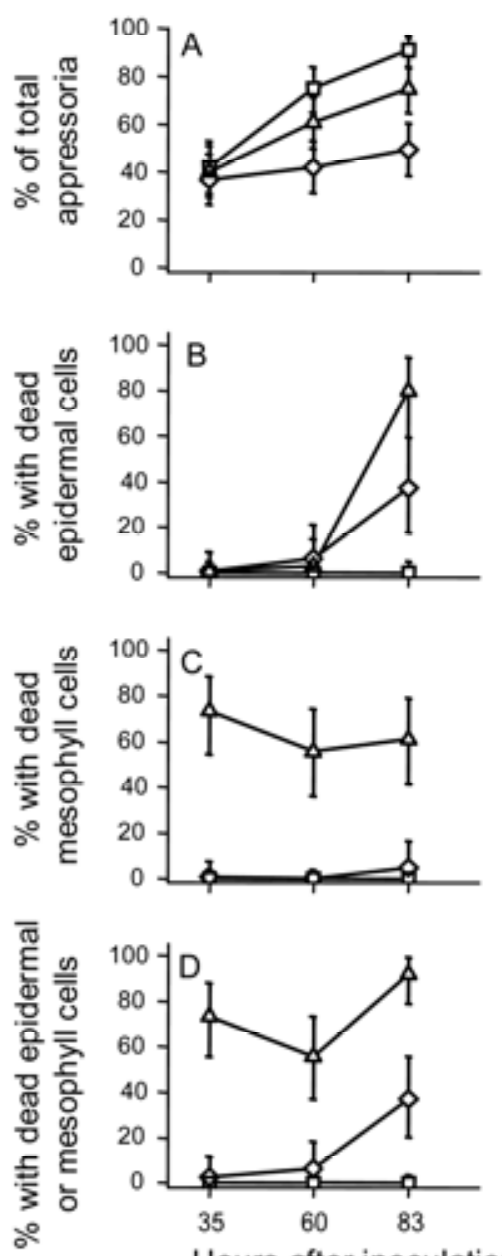

Hours after inoculation
Failed penetration (no haustorium)

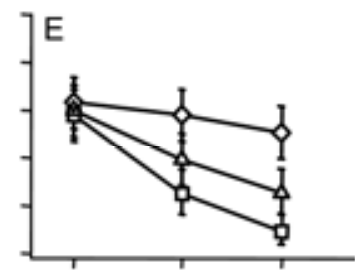

Total attacks
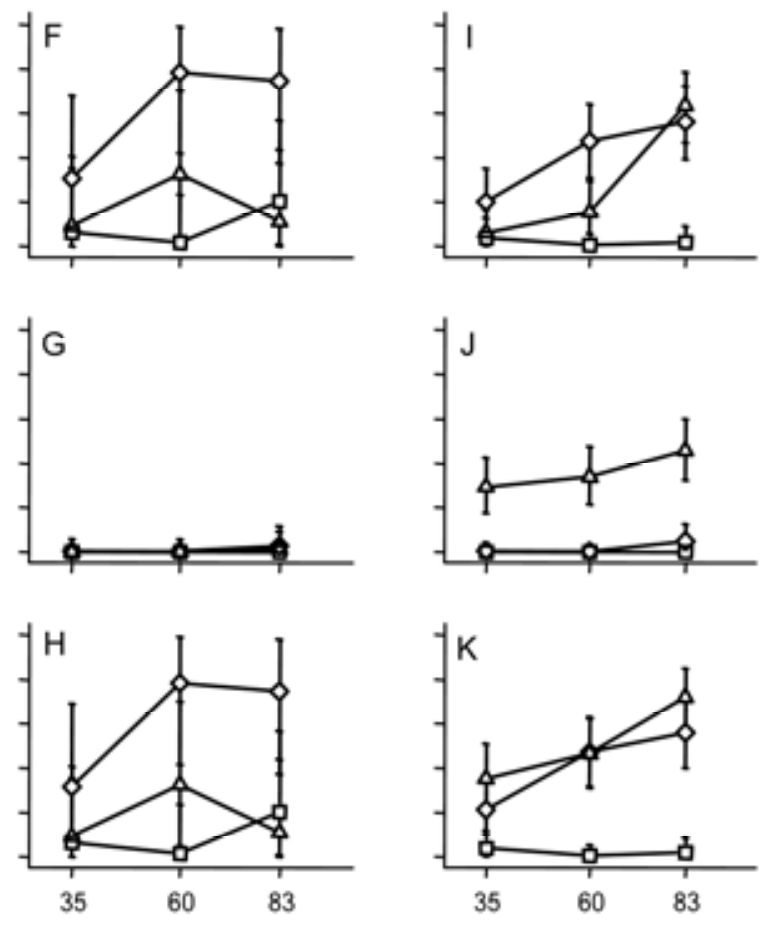

Hours after inoculation
Hours after inoculation

Fig. 4. Blumeria graminis f. sp. hordei development and plant cell responses at various times after inoculation $\left(100 \mathrm{conidia}^{\mathrm{mm}} \mathrm{m}^{-2}\right)$ with barley $\mathrm{cv}$. Pallas (susceptible; $\square$ ) and the resistant isolines P02 (Mla3; $\triangle$ ) and P23 (MlLa; $\diamond)$. Data are based on observations of 50 randomly selected attack sites on each of three replicate leaves from every barley line at all sample times. Bars indicate $95 \%$ confidence intervals. 
indicating cell death and correspondingly no chlorophyll fluorescence was detected. In the dried sample, the previously open stomata were closed (Fig. 9C and D). Thus, the locking open of guard cells adjacent to attacked epidermal cells required that they remain alive. Similar results were obtained with P02 and P23 (Fig. 9E and F) where, again, autofluorescence of epidermal cells was associated with open stomata and stomata closed after drying and their chloroplasts ceased to fluoresce (data not shown).

\section{DISCUSSION}

It is well established that infection by biotrophic fungi such as the rusts and powdery mildews affect stomatal function and in rust, compatible and incompatible interactions lead to stomata becoming locked shut (21). Clearly, the underlying mechanisms for this could be similar to those described for flg22 effects on Arabidopsis stomata $(20,32)$. In contrast, the lock-open mechanism we have described in barley interactions with $B$. graminis $\mathrm{f}$.

\section{Experiment 2}

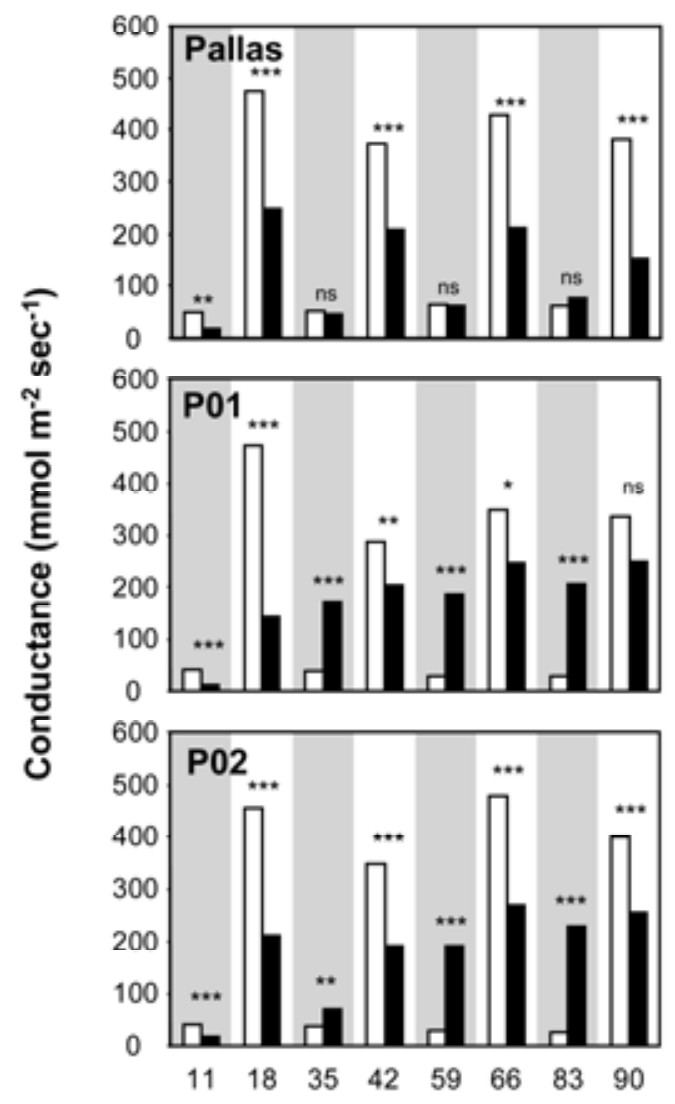

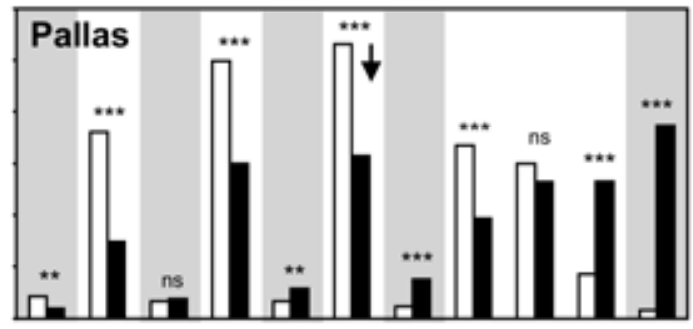
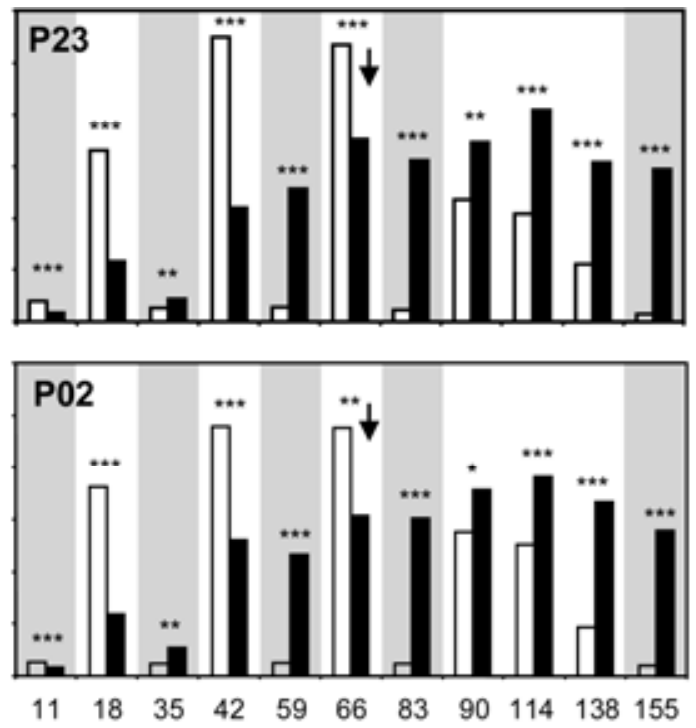

\section{Hours after inoculation}

Fig. 5. Time course of leaf water conductance $\left(g_{1}\right)$ of healthy $(\square)$ and inoculated ( $\square$ ) Pallas, P01, P02, and P23 barley leaves measured $1 \mathrm{~h}$ before the end of each dark period (indicated by gray-shaded segments) or in mid-light period (unshaded), when incubated under a $12 \mathrm{~h}$ dark/12 h light cycle in two independent experiments. Experiment 1 used Pallas, P01, and P02 plants that were well watered until the experiment was terminated after $90 \mathrm{~h}$. Experiment 2 used Pallas, P23, and P02 plants that were well watered until immediately after the $66 \mathrm{~h}$ reading (arrow) when water was withheld and further readings were made at intervals up to $155 \mathrm{~h} . *, * *$, and $* * *$ above a data pair indicate significant difference between healthy and inoculated at $P<0.05,0.01$, and 0.001 , respectively; ns indicates no significant difference.

TABLE 1. Frequencies and outcomes of Blumeria graminis f. sp. hordei interactions with type A epidermal cells of different barley isolines inoculated with 100 conidia $\mathrm{mm}^{-2}$ in experiments 1 and $2^{\mathrm{a}}$

\begin{tabular}{llccr}
\hline & & \multicolumn{3}{c}{ Percentage of stomatal complexes } \\
\cline { 3 - 5 } Experiment & Barley line & $\begin{array}{c}\text { Adjacent to cells attacked } \\
\text { by appressorium }\end{array}$ & $\begin{array}{c}\text { Adjacent to living epidermal cell } \\
\text { containing a haustorium }\end{array}$ & $\begin{array}{c}\text { Adjacent to dead epidermal cell or } \\
\text { epidermal cell overlying dead mesophyll cell }\end{array}$ \\
\hline 1 & Pallas & $57.5( \pm 7.5)$ & $19.2( \pm 5.8)$ & $7.5( \pm 2.5)$ \\
& P01 & $43.3( \pm 2.9)$ & $0.0^{\mathrm{b}}$ & $36.7( \pm 7.2)$ \\
& P02 & $59.2( \pm 8.8)$ & $5.8( \pm 1.4)$ & $49.2( \pm 2.9)$ \\
& Pallas & $60.8( \pm 10.1)$ & $21.7( \pm 3.8)$ & $5.0( \pm 5.0)$ \\
& P02 & $57.5( \pm 2.5)$ & $7.5( \pm 2.5)$ & $48.3( \pm 5.2)$ \\
& P23 & $58.3( \pm 10.5)$ & $14.2( \pm 1.4)$ & $50.8( \pm 6.3)$ \\
\hline
\end{tabular}

${ }^{a}$ In all cases, means ( \pm standard deviation) are based on observation of type A cells associated with 40 stomatal complexes in each of three replicate leaves of each barley line in both experiments.

${ }^{b}$ Data not subject to statistical analysis. 
sp. hordei (23) is likely to reflect discrete pathogen-mediated effects on mechanisms which regulate closure and/or opening. However, prior to any mechanistic characterization of lock-up, the relationship between host response to $B$. graminis f. sp. hordei and stomatal activity requires precise characterization. Here, we show that the effects on stomatal responses of B. graminis f. sp. hordei infection on barley fall into two distinct categories. There is a rapid reduction of $g_{1}$ in the light in response to infection in both susceptible and resistant genotypes when the resistance is based on the Mla1, Mla3, or MlLa alleles. Since this effect occurs in the very early stages of infection (from $\approx 4$ to 11 hai) before fungal penetration occurs and is only slightly dependent on the density of inoculum it likely reflects early signaling events, and implications will be discussed below. The second effect is the lock-open of stomata in the dark, resulting in an increased dark $g_{1}$, a more quantitative effect which is shown to be related to the development of an HR in epidermal cells adjacent to stomata. Here we provide evidence that locked open stomata occur when a living guard cell is near to a dead epidermal cell and can close when it looses turgor. This change is associated with a change in the ability of chlorophyll to fluoresce but further measurements are required to confirm if this is accompanied by changes in photosynthetic activity.

The initial reduction in $g_{1}$ in response to mildew infection occurs in all of the $B$. graminis f. sp. avenae/barley and $B$. graminis $\mathrm{f}$. sp. hordei/barley interactions studied here and previ-
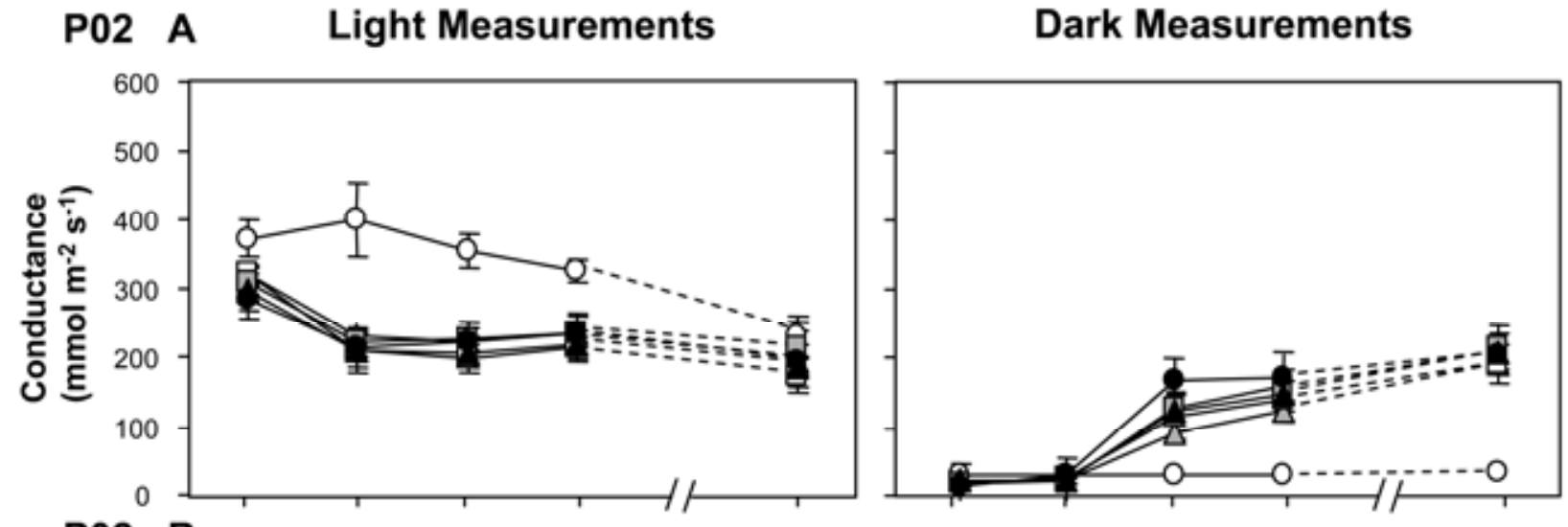

P02 B
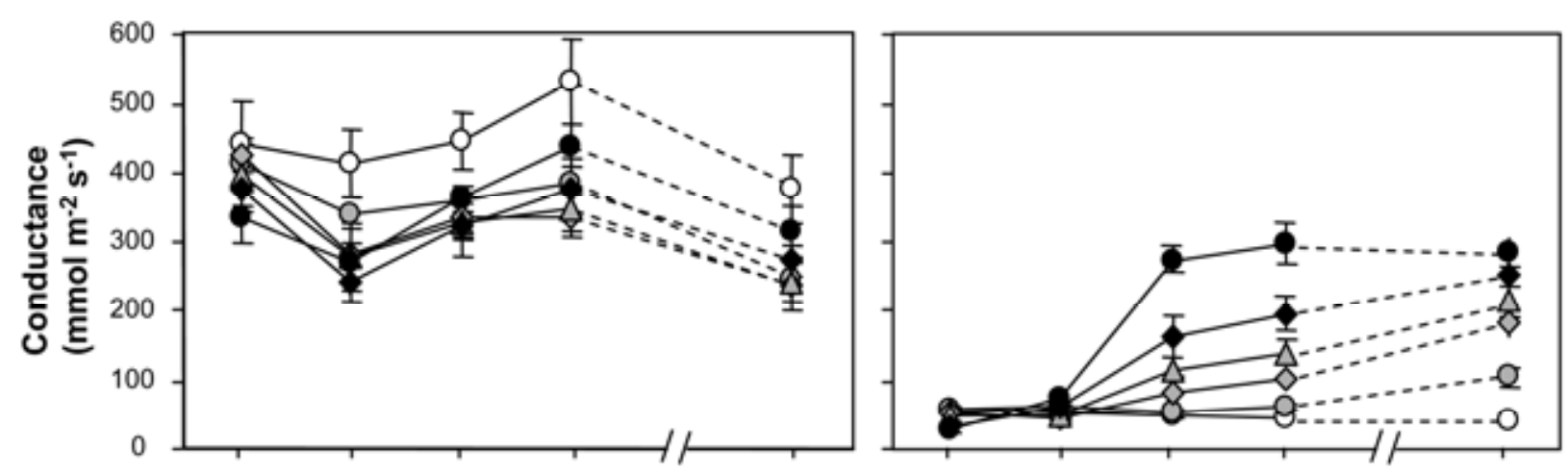

P01 C
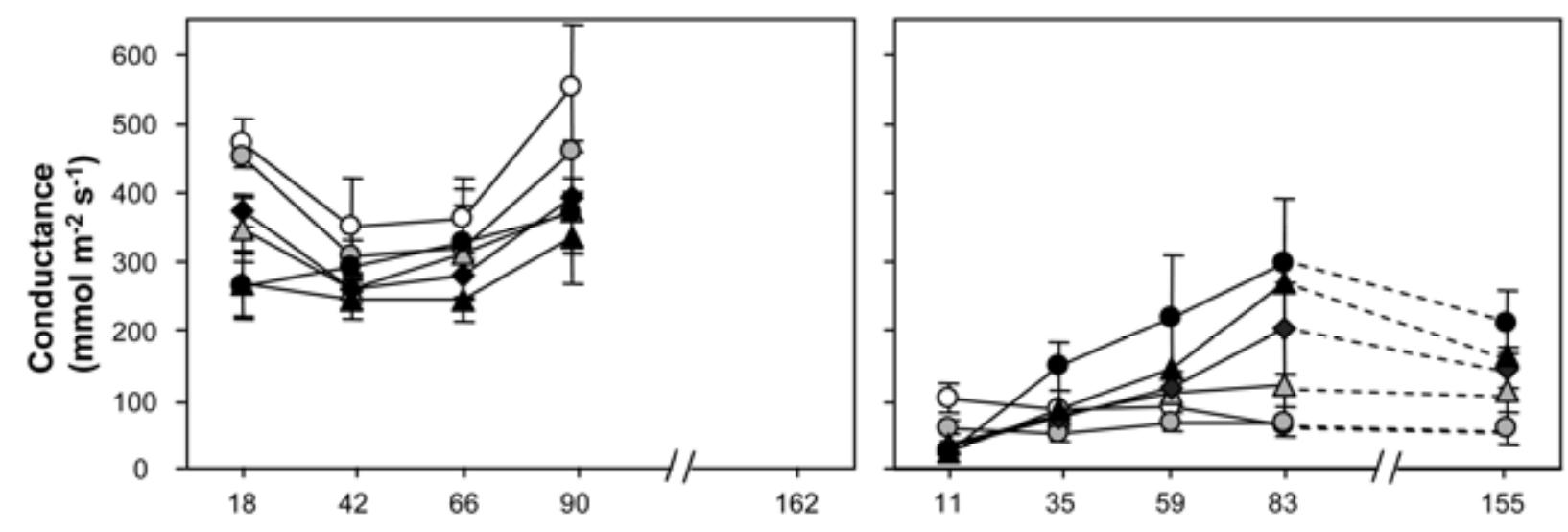

Hours after inoculation

$$
\bullet=100 ; \boldsymbol{\square}=80 ; \square=60 ; \boldsymbol{\Delta}=50 ; \square=40 ; \bullet=20 ; \Delta=10 ; \diamond=5 ; 0=1 ; 0 \text { =uninoculated; }
$$

Fig. 6. Time course of leaf water conductance $\left(g_{1}\right)$ in healthy leaves and leaves of A and B, P02 and C, P01 inoculated with different densities of Blumeria graminis f. sp. hordei conidia (20,40,60,80, and 100 conidia $\mathrm{mm}^{-2}$ in $\mathbf{A} ; 1,5,10,20$, and 100 conidia $\mathrm{mm}^{-2}$ in $\mathbf{B} ;$ and $1,10,20,50$, and 100 conidia mm ${ }^{-2}$ in $\mathbf{C}$ ), and measured in mid-light period and $1 \mathrm{~h}$ before the end of successive dark periods under a $12 \mathrm{~h}$ dark/12 h light cycle during incubation. Light and dark measurements were obtained from the same leaves within separate experiments, but are separated for comparison. Bars indicate $95 \%$ confidence intervals. 
ously (23). Thus, it is a nonspecific response and the factors controlling it are unknown. It may be the result of the contact of spores on the epidermis affecting the hydraulic conditions of the guard and subsidiary cells since their water supplies come via the epidermis; this type of effect would act very quickly. It may also be regulated by signaling compounds (such as ABA or NO) diffusing from spores, analogous to that demonstrated for ABA from Botrytis cinerea (28). In this context, we have recently demonstrated that NO production from the fungus plays an essential role in pathogenesis (22). It could also be a response to signals produced by the plant as a response to the presence of active spores or compounds diffusing from them. Longer acting factors such as increased respiration and photorespiration which would increase internal $\left(\mathrm{CO}_{2}\right)$ and thus reduce stomatal aperture have also been suggested (1). Thus, further work is required to elucidate these and other possible mechanisms. This work would be valuable in understanding how to reduce the costs, in terms of the lost photosynthesis caused by the reduction in $g_{1}$, which persisted until leaves senesced in resistant lines. Since the same responses of $g_{1}$, were also seen with the nonpathogen $B$. graminis f. sp. avenae attack it will be important to establish how general this phenomenon is and to evaluate its effect on crop yield as reducing these responses may also offer a route to improve crop yields.

Our earlier study (23) provided the first evidence that cell death caused by $B$. graminis f. sp. hordei attack in barley led to stomatal lock-open. The current evidence extends this to three different $B$. graminis f. sp. hordei resistance alleles and importantly to a nonpathogen (B. graminis f. sp. avenae) of barley, and in all cases increases in dark $g_{1}$ were noted, with the timing and magnitude of the changes involved being dependent on the particular interaction studied. Recent reviews discuss the costs of resistance in terms of reduced crop yield $(5,24)$. In considering HR, the principal concern to date has been the transient increases in respiration

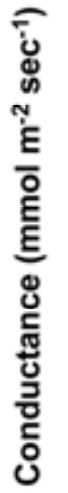
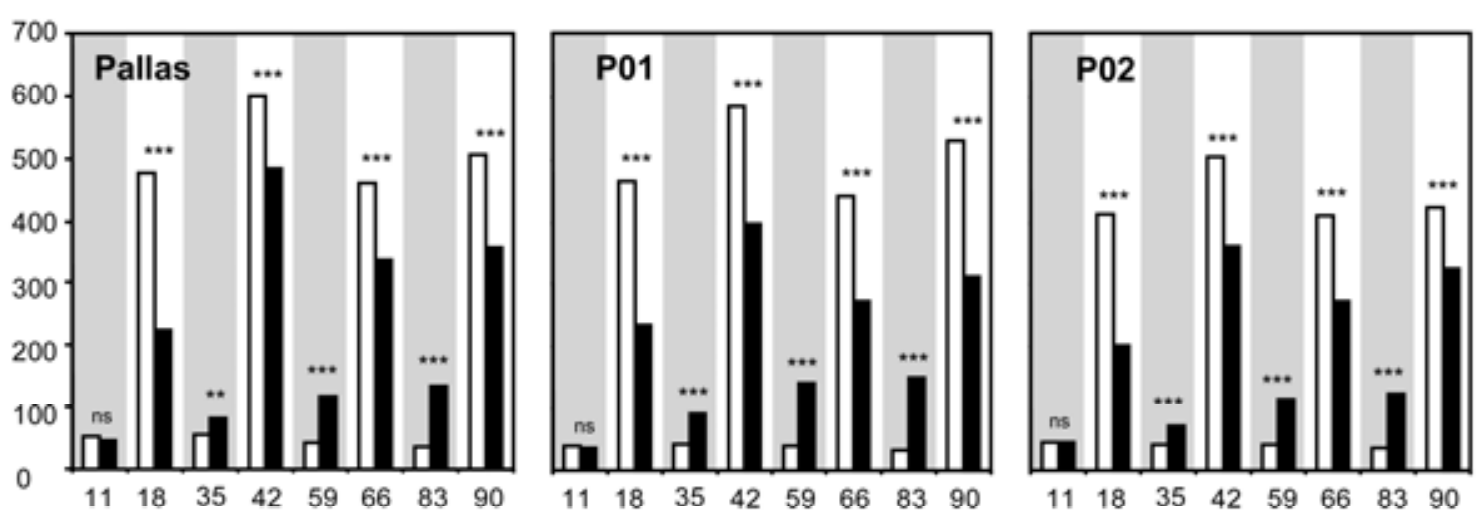

Hours after inoculation

Fig. 7. Time course of leaf water conductance $\left(g_{1}\right)$ of healthy $(\square)$ Pallas, P01, and P02 barley leaves and leaves inoculated (匹) with the nonhost fungus Blumeria graminis f. sp. avenae, measured $1 \mathrm{~h}$ before the end of each dark period (indicated by gray-shaded segments) or in mid-light period (unshaded) when incubated under a $12 \mathrm{~h}$ dark/12 h light cycle. *, **, and *** above a data pair indicate significant difference between healthy and inoculated at $P<0.05,0.01$, and 0.001 , respectively; ns indicates no significant difference.
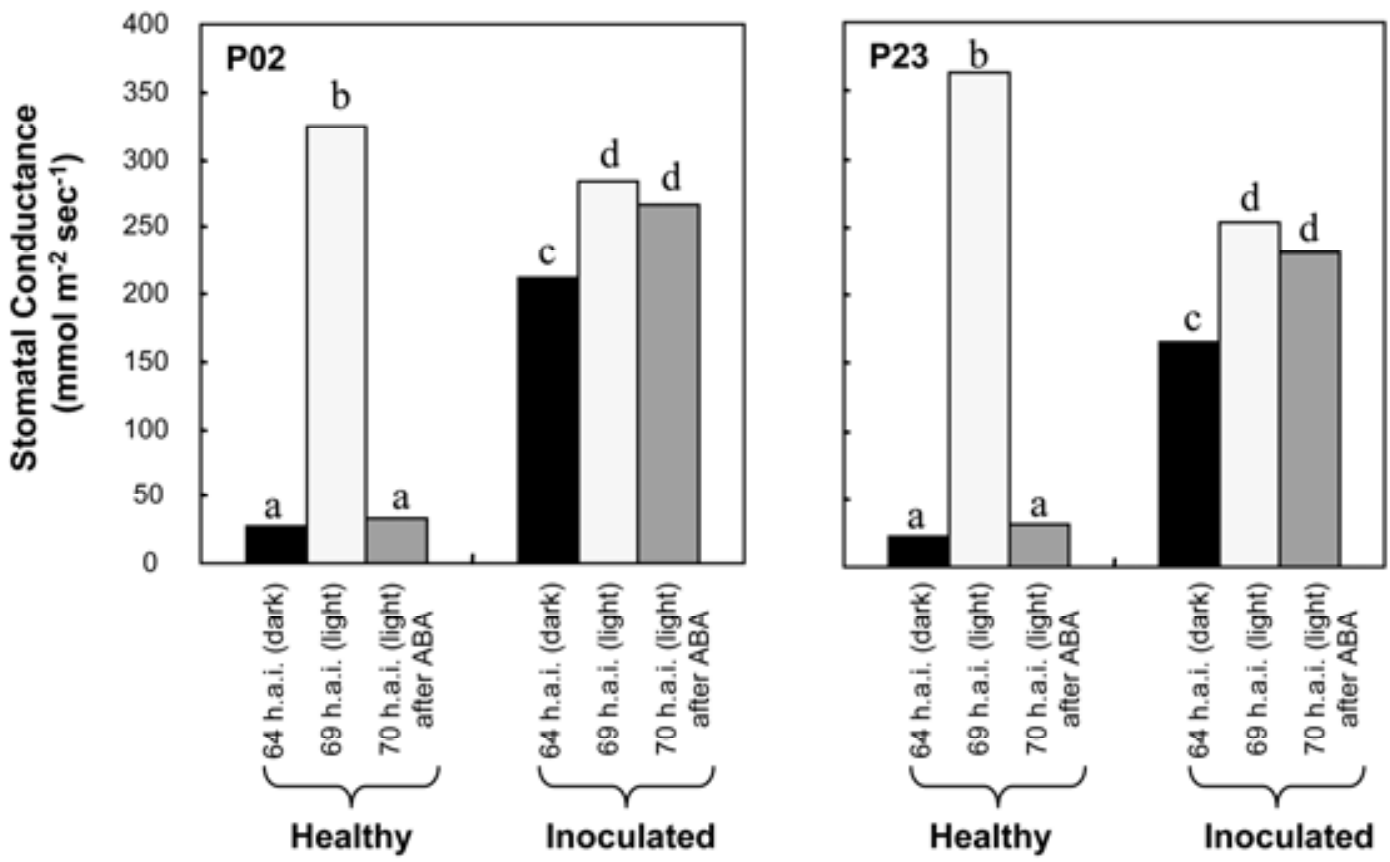

Fig. 8. Leaf water conductance ( $\left.g_{1}\right)$ of healthy and inoculated P02 and P23 barley leaves measured in darkness at $64 \mathrm{~h}$ after inoculation (hai) (black bars) and then in light at 69 hai (white bars) and again 70 hai in light, $30 \mathrm{~min}$ after application of abscisic acid (gray bars). Different letters above bars indicate significant difference $(P<0.001)$. 
associated with HR $(29,30)$. However, the increases in dark $g_{1}$ associated with HR are important as they may lead to increased water use by the crop, and this would reduce the grain filling period in drier seasons, leading to reduced yield. Because this effect also occurs with nonpathogens (such as B. graminis f. sp. avenae on barley) and may have the same consequences in terms of water use, this is an important physiological response that may have to be considered in crop improvement programs where crops may be exposed to significant levels of nonpathogenic inoculum and HR resistance is functioning.

Microscopy generally confirmed results from earlier studies showing that Mlal, Mla3, and MlLa condition spatial and temporal patterns of cell death that are unique to each gene and explain the macroscopic disease phenotype associated with them $(4,6,14)$. Apart from the general differences in timing and site of action of HR a quite different situation was evident with MlLa
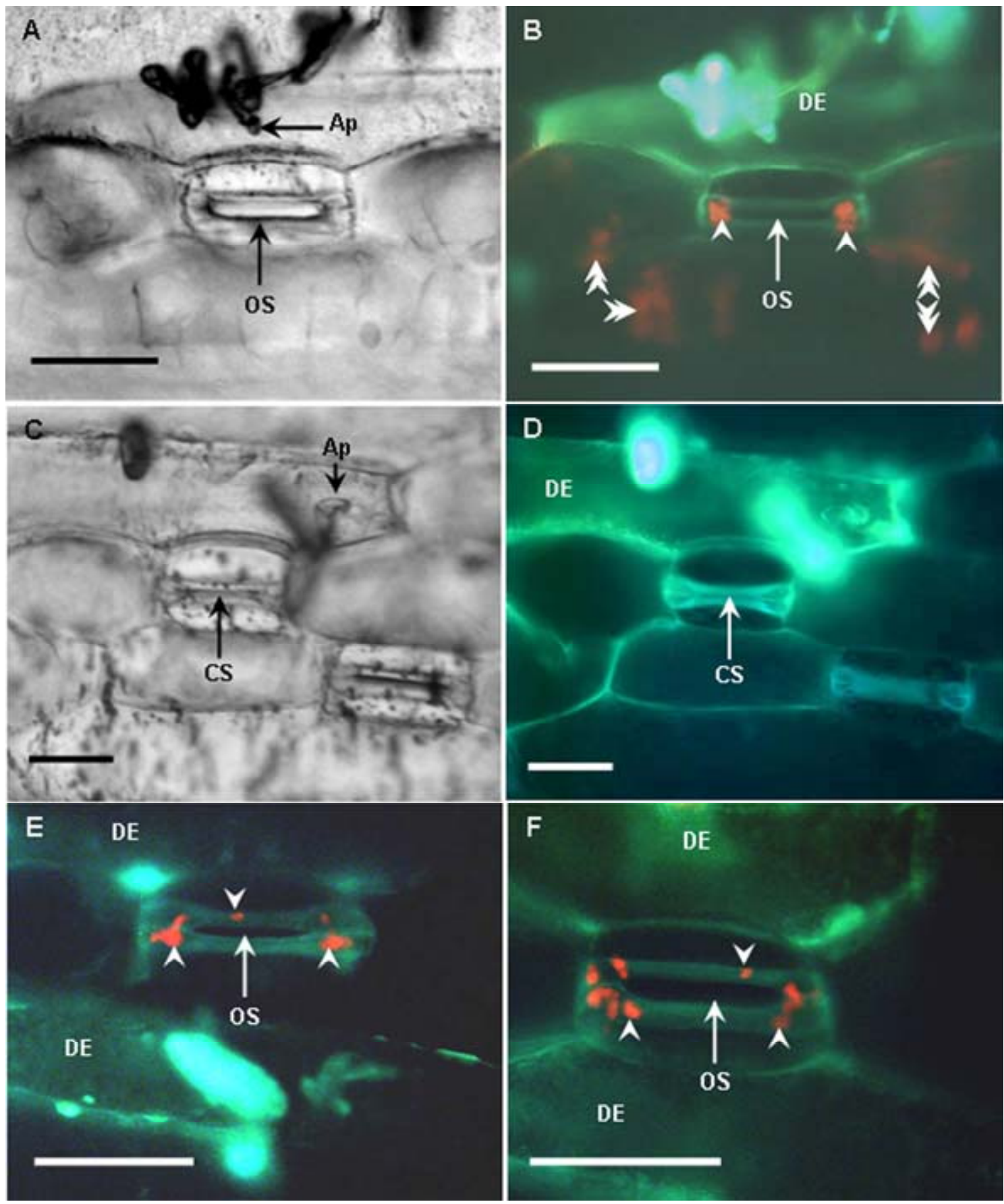

Fig. 9. Chlorophyll autofluorescence in chloroplasts. A, Transmitted light view of a locked open stoma (OS) in an epidermal strip of P01 removed in darkness, 55 $\mathrm{h}$ after inoculation (hai). Blumeria graminis f. sp. hordei spores and an appressorium (Ap) lie on the epidermal cell above the stoma. B, Same view as in A under blue incident light, showing yellow-green whole-cell fluorescence in the epidermal cell (DE) above the stoma indicating cell death and red-fluorescent chloroplasts (single arrowheads) in guard cells. Remnant chloroplasts from mesophyll damaged during preparation are out of focus beneath the epidermis (double arrowheads). C, Transmitted white light view of the same epidermal strip shown in A and B after air drying. The central stoma is closed (CS) but an appressorium (Ap) lies on the epidermal cell above. D, Same view as $\mathbf{C}$ under blue incident light. The epidermal cell above shows yellow-green whole-cell fluorescence but the walls of adjacent epidermal cells and the guard cells are also fluorescent. No red chlorophyll fluorescence is visible within the guard cells. E, Abaxial epidermal strip from P02 taken in darkness 66 hai under incident blue light. Guard cells of the open stoma (OS) contain brightly red fluorescent chloroplasts while epidermal cells $(\mathrm{DE})$ above and below the stoma show yellow-green fluorescence indicating that they are dead. F, Similar to $\mathbf{E}$ but the epidermal strip was from P23. Bars = $50 \mu \mathrm{m}$ in all cases. 
where individual epidermal cells differed greatly in their rapidity of response. This is similar to that in Mla12 where some epidermal cells undergo HR almost immediately after penetration whereas others survive and allow haustoria to develop $(10,11)$. In Mla12 barley, rapid cell death is associated with cell-wide $\mathrm{H}_{2} \mathrm{O}_{2}$ generation (as is the general rule for $\mathrm{HR}$ ) whereas haustorium formation is associated with $\mathrm{O}_{2}{ }^{-}$and the absence of $\mathrm{H}_{2} \mathrm{O}_{2}(10,11)$, but the basis of this difference, and why neighboring epidermal cells should show such a contrasting response in Mla12 and MlLa barleys to similar penetration events, remains unexplained.

Prats et al. (23) argued that papilla-based resistance offers an attractive means of powdery mildew control because, unlike HR, it (i) has only a transient effect on $g_{1}$, (ii) has proved effective and durable in mlo barley cultivars (27), and (iii) is considered an "energetically frugal means of plant defense" (19). However, this form of resistance has been less used than $R$ gene-based resistance since it is mostly quantitative and under complex genetic control making it difficult to select for in breeding programs. In addition to the proven ephemerality of $R$ gene resistance due to the rapid evolution of pathogen virulence, we demonstrate that an $R$ gene that induces an HR disrupts stomatal function and has consequences for lost control of photosynthesis, respiration, and efficient water use as well as reducing the ability to respond to abiotic stress. Our examination of effects of inoculum density provided cause for concern. With $\mathrm{P} 02$, even low inoculum density ( 1 conidium $\mathrm{mm}^{-2}$ ) suppressed light $g_{1}$ within 2 days, thus reducing photosynthetic potential and led to relatively high dark $g_{1}$, presumably because increasing numbers of underlying mesophyll cells and previously infected epidermal cells died and caused lock-open of stomata increasingly distant from the site of primary infection. By contrast, with P01 there was a stronger correlation between the inoculum density and effects on $g_{1}$, presumably a consequence of focused, rapid response associated with Mlal resistance. A similar response was observed when each cultivar was challenged with $B$. graminis f. sp. avenae. Hence, if there is no alternative to the use of $R$ genes, the data strongly indicate the desirability of using genes or alleles that condition a rapid, spatially focused HR to limit consequential costs, and screening for minimal increases in dark $g_{1}$ that occurred rapidly after infection would be an effective method to detect this material. Also, screening of responses to nonpathogens may help to eliminate potentially sensitive material. It is important to note in this context that all of our results were developed on seedling material, which can be produced and screened at relatively low cost.

\section{ACKNOWLEDGMENTS}

E. Prats was supported by a Marie Curie European Reintegration Grant and by the project AGL2007-65031/AGR, T. Carver and B. Thomas by Defra Project AR0712, and A. P. Gay by ERDF interreg. IIIB Atlantic Area Project 190 (PIMHAI).

\section{LITERATURE CITED}

1. Ayres, P. G. 1981. Powdery mildew stimulates photosynthesis in uninfected leaves of pea plants. J. Phytopathol. 100:312-318.

2. Ayres, P. G. 1981. Stomatal physiology. Pages 205-222 in: Soc. Exp. Biol. Seminar Series 8. P. G. Jarvis and T. A. Mansfield, eds. Cambridge University Press.

3. Ayres, P. G., and Zadoks, J. C. 1979. Combined effects of powdery mildew disease and soil water level on the water relations and growth of barley. Physiol. Plant Pathol. 14:347-361.

4. Boyd, L. A., Smith, P. H., Foster, E. M., and Brown, J. K. M. 1995. The effects of allelic variation at the Mla resistance locus in barley on the early development of Erysiphe graminis f. sp. hordei and host responses. Plant J. 7:959-968.

5. Brown, J. K. M. 2002. Yield penalties of disease resistance in crops. Curr. Opin. Plant Biol. 5:339-344.

6. Carver, T. L. W., and Williams, O. 1980. The influence of photoperiod on growth patterns of Erysiphe graminis f. sp hordei. Ann. Appl. Biol. 94:405-414.
7. Green, J. R., Carver, T. L. W., and Gurr, S. J. 2002. The formation and function of infection and feeding structures. Pages 66-82 in: Powdery Mildews: A Comprehensive Treatise. R. R. Belanger, W. R. Bushnell, A. J. Dik, and T. L. W. Carver, eds. American Phytopathological Society, St. Paul, MN.

8. Guimarães, R. L., and Stotz, H. U. 2004. Oxalate production by Sclerotinia sclerotiorum deregulates guard cells during infection. Plant Physiol. 136:3703-3711.

9. Hamilton, D. W. A., Hills, A., Kohler, B., and Blatt, M. R. 2000. $\mathrm{Ca}^{2+}$ channels at the plasma membrane of stomatal guard cells are activated by hyperpolarization and abscisic acid. Proc. Natl. Acad. Sci. USA 97:4967-4972.

10. Hückelhoven, R., Fodor, J., Preis, C., and Kogel, K. H. 1999. Hypersensitive cell death and papilla formation in barley attacked by the powdery mildew fungus are associated with hydrogen peroxide but not with salicylic acid accumulation. Plant Physiol. 119:1251-1260.

11. Hückelhoven, R., and Kogel, K. H. 1998. Tissue-specific superoxide generation at interaction sites in resistant and susceptible near isogenic barley lines attacked by the powdery mildew fungus (Erysiphe graminis $\mathrm{f}$. sp. hordei). Mol. Plant-Microbe Interact. 11:292-300.

12. Jørgensen, J. H. 1994. Genetics of powdery mildew resistance in barley. Crit. Rev. Plant Sci. 13:97-119.

13. Koga, H., Bushnell, W. R., and Zeyen, R. J. 1990. Specificity of cell type and timing of events associated with papilla formation and the hypersensitive reaction in leaves of Hordeum vulgare attacked by Erysiphe graminis f. sp. hordei. Can. J. Bot. 68:2344-2352.

14. Kølster, P., Munk, L., Stolen, O., and Lohde, J. 1986. Near isogenic barley lines with genes for resistance to powdery mildew. Crop Sci. 26:903-907.

15. Kruger, W. M., Carver, T. L. W., and Zeyen, R. J. 2002. Effects of inhibiting phenolic biosynthesis on penetration resistance of barley isolines containing seven powdery mildew resistance genes or alleles. Physiol. Mol. Plant Pathol. 61:41-51.

16. Leckie, C. P., McAinsh, M. R., Allen, G. J., Sanders, D., and Hetherington, A. M. 1998. Abscisic acid-induced stomatal closure mediated by cyclic ADP-ribose. Proc. Natl. Acad. Sci. USA 95:15837-15842.

17. Livingstone, D. M., Hampton, J. L., Phipps, P. M., and Grabau, E. A. 2005. Enhancing resistance to Sclerotinia minor in peanut by expressing a barley oxalate oxidase gene. Plant Physiol. 137:1354-1362.

18. Lyngkjær, M. F., Carver, T. L. W., and Zeyen, R. J. 2001. Virulent Blumeria graminis infection induces penetration susceptibility and suppresses race-specific hypersensitive resistance against avirulent attack in Mla1-barley. Physiol. Mol. Plant Pathol. 59:243-256.

19. Mellersh, D. G., Foulds, I. V., Higgins, V. J., and Heath, M. C. 2002. $\mathrm{H} 2 \mathrm{O} 2$ plays different roles in determining penetration failure in three diverse plant-fungal interactions. Plant J. 29:257-268.

20. Melotto, M., Underwood, W., Koczan, J., Nomura, K., and He, S. Y. 2006. Plant stomata function in innate immunity against bacterial invasion. Cell 126:969-980.

21. Prats, E., Carver, T. L. W., Gay, A. P., and Mur, L. A. J. 2007. Enemy at the gates: Interaction-specific stomatal responses to pathogenic challenge. Plant Sign. Behav. 2:275-277.

22. Prats, E., Carver, T. L. W., and Mur, L. A. J. 2008. Pathogen-derived nitric oxide influences formation of the appressorium infection structure in the phytopathogenic fungus Blumeria graminis. Res. Microbiol. 159:476-480.

23. Prats, E., Gay, A. P., Mur, L. A. J., Thomas, B. J., and Carver, T. L. W. 2006. Stomatal lock-open, a consequence of epidermal cell death, follows transient suppression of stomatal opening in barley attacked by Blumeria graminis. J. Exp. Bot. 57:2211-2226.

24. Purrington, C. B. 2000. Costs of resistance. Curr. Opin. Plant Biol. 3:305-308.

25. Roelfsema, M. R. G., and Hedrich, R. 2005. In the light of stomatal opening: New insights into 'the Watergate'. New Phytol. 167:665-691.

26. Schroeder, J. I., Kwak, J. M., and Allen, G. J. 2001. Guard cell abscisic acid signalling and engineering drought hardiness in plants. Nature 410:327-330.

27. Schulze-Lefert, P., and Panstruga, R. 2003. Establishment of biotrophy by parasitic fungi and reprogramming of host cells for disease resistance. Annu. Rev. Phytopathol. 41:641-667.

28. Siewers, V., Smedsgaard, J., and Tudzynski, P. 2004. The P450 monooxygenase BcABA1 is essential for abscisic acid biosynthesis in Botrytis cinerea. Appl. Environ. Microbiol. 70:3868-3876.

29. Smedegaard-Petersen, V., and Stølen, O. 1981. Effect of energy requiring defense reactions on yield and grain quality in a powdery mildew resistant barley cultivar. Phytopathology 71:396-399.

30. Smedegaard-Petersen, V., and Tolstrup, K. 1985. The limiting effect of disease resistance on yield. Annu. Rev. Phytopathol. 23:475-490.

31. Staxen, I., Pical, C., Montgomery, L. T., Gray, J. E., Hetherington, A. M., and McAinsh, M. R. 1999. Abscisic acid induces oscillations in guard-cell cytosolic free calcium that involve phosphoinositide-specific phospholipase C. Proc. Natl. Acad. Sci. USA 96:1779-1784.

32. Zhang, W., He, S. Y., and Assmann, S. M. 2008. The plant innate immunity response in stomatal guard cells invokes G-protein-dependent ion channel regulation. Plant J. 56:984-996. 